\title{
Christopher Brennan
}

University of Tampere, Finland

https://doi.org/10.18778/1733-8077.10.3.05

\section{Backpackers or Working Holiday Makers? Working Tourists in Australia}

Abstract This article looks at a potential divergence of characteristics between backpackers and working holiday makers in Australia. While both are often lumped together within academic study, working holiday makers have a legal right to pursue employment and are entitled to rights and standards of work that come with paid employment, whereas backpackers, as young budget travelers, do not. Drawing on data from autoethnographic fieldwork, qualitative interviews, and empirical analysis of previous studies, this article identifies a conceivable divergence between backpackers and working holiday makers in Australia: the activity of paid employment. The investigation highlights empirical factors and circumstances that contribute to a separation as compared to previous discussions and studies. The paper concludes by suggesting that more emphasis should be given to working holiday makers as a distinct group of working tourists who, in fact, have rights as workers, disjoining them from the label "backpacker," which is more commonly understood as a form of young budget tourist.

Keywords Working Holiday Makers; Autoethnography; Backpackers; Working Tourists; Working Holiday

mid the backpacker masses that traverse 1 Australia each year - seeking surf and sun - many do so under the auspices of Australia's Working Holiday Maker Program (WHMP). This program involves the offering by the Australian

Christopher Brennan is a doctoral candidate in sociology at the University of Tampere, Finland. His research and dissertation examine the precarious work situations of working tourists in Australia. He embraces qualitative research methods and his research interests include various topics within work, tourism, and international mobility.

email address: christopher.brennan@uta.fi
Government of two visa categories ${ }^{1}$ to young travelers between the ages of 18 and 31 from select countries around the world, providing them a legal right to live and work in Australia for up to a year, with the possibility for a second year stay for some upon completion of work in certain Australia industries. ${ }^{2}$ The program was initiated in 1975 and has been operated with the intent of promoting cultural exchange and letting internation-

${ }^{1}$ Working Holiday Visa (Subclass 417): For persons from Belgium, Canada, Republic of Cyprus, Denmark, Estonia
Finland, France, Germany, Hong Kong, Republic of Ireland Italy, Japan, Republic of Korea, Malta, Netherlands, Norway, Sweden, Taiwan, and United Kingdom. Work and Holiday Vis (Subclass 462): For persons from Argentina, Bangladesh, Chile, Indonesia, Malaysia, Thailand, Turkey, and the U.S.A. ${ }^{2}$ This possibility is only available to WHV 417 holders. al youth tour and learn about the country for an extended period while supplementing travel with paid employment (Gallus 1997; Harding and Webster 2002; Tan et al. 2009). However, employment restrictions exist - one cannot work with any one employer beyond a 6-month period. The program has expanded since inception to incorporate more participant countries, as well as the offering of the second visa mentioned. Subsequently, the number of working holiday makers in Australia has risen throughout the years; in fact, the number has grown significantly from almost 6,000 visa arrivals in 1983-1984 to over 134,000 by 2007-2008 (Department of Immigration and Citizenship [DIAC] 2012). Likewise, the number of visas granted ${ }^{3}$ has increased considerably from almost 158,000 in 2007-2008 to nearly 223,000 , almost a quarter million, in 2011-2012 (DIAC 2012).

While working holiday makers (WHMs), those travelers who possess either of the WHMP visas, have a legal right to work, they are very often bundled by Australian media into the same generalized social class of another prevalent category of international travelers in Australia - "backpackers" (see: Walliker 2007; The Age 2008; Jensen 2009; Tovey 2012; Colley 2013; Opie 2013). ${ }^{5}$ They are even included within academic studies of backpackers

Older studies have utilized "visa arrivals" and more recent studies "visa grantings," hence, the use of different statistical

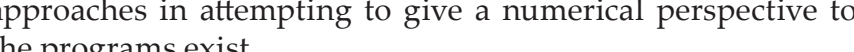

These numbers are cumulative totals from combining totals of the two charts representing grantings for WHV 417 and

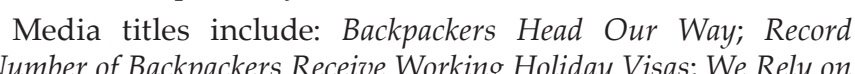
Backpacker: Gaeta; Hopping Mad: Backpackers Fume Over Broken Promise of Fruit-Picking Work; Blitz on Working Holiday Visa Scam. This is just an example, as many more exist. in Australia (see: Locker-Murphy and Pierce 1995; Allon, Bushell, and Anderson 2008). Yet, aside from the informal "backpacker" sticker attached to them, there have also been Australian government funded studies about this particular group alone (see: Dignam 1990; Withers 1991; Bell and Carr 1994; Brooks, Murphy, and Williams 1994; Murphy 1995; Parliamentary Joint Standing Committee on Migration 1997; Harding and Webster 2002; Tan et al. 2009), often discussing their effect on the Australian labor market (see: Harding and Webster 2002; Tan et al. 2009). There has also even been a study about Japanese working holiday makers in Australia and their effect on Japan's labor market (see: Kawashima 2012). Such distinction in study shows that, at times, they are indeed acknowledged as a clear group, yet the "backpacker" label often still prevails within an Australian context due to WHMs exploratory nature and touristic tendencies, not to mention their enormous contribution in spending towards the Australian tourism industry. As reported by the Australian Tourism Export Council, the peak body for the Australian inbound tourism industry, in their position paper "The Importance of the Working Holiday Visa (Subclass 417)," “[b]ackpackers stay [in Australia] an average of 73 nights and spend over $\$ 5,400$, while working holiday makers have an extended stay averaging 8 months and spend over \$13,000 each" (ATEC 2012:3). While the ATEC may separate the groups in terms of spending, it later goes to state in the same document that, "the WHM program is a significant driving force in attracting backpackers to Australia" (2012:5), subsequently re-identifying their common casual association together. Further, the ATEC also states, 
“[w]orking holiday makers are particularly important to the backpacker market, with a strong correlation between the WHM program visitor and the inbound backpacker" (2012:8). Studied separately or together, from a tourism industry standpoint, backpackers and working holiday makers are the same, joined by their quest of travel. In differentiating between the two though, a pursuit of work characteristic is key; working holiday makers pursue a legal right to work in applying for their visas, and in return, have a legal right to work when in Australia, followed by taxation of wages and rights when applicable. "Backpackers," as travelers or tourists, have no legal right to work, nor are they taxed, nor are they protected in the work place. In most academic contexts, "backpackers" have customarily been studied as type of budget travelers who chases an alternative form of leisure and travel based activities, in contrast to conformist notions of "tourists."

Drawing on autoethnographic participant observation, qualitative interviews, and previous studies of backpackers in Australia, this article discusses a contemporary divergence in characteristics and label of these two groups of international travelers backpackers and working holiday makers. It is suggested that a need for more colloquial recognition of working holiday makers as not only a distinct type of international working tourists is necessary but also hopefully to draw more attention to their own situations and roles as workers, as well.

\section{Backpackers}

When trying to categorize just who backpackers are, academia has approached the task utilizing different characteristics. For example, backpackers have been categorized into a socio-demographic category as being largely young people in the age range of 15-25 (Locker-Murphy and Pearce 1995; Sørensen 2003). Observing activity, Sørensen identifies backpackers as "a group seen as self organized pleasure tourists on a prolonged multiple destination journey with a flexible itinerary, extended beyond that which it is usually possible to fit into a cyclical holiday pattern" (2003:851). Backpackers are also known for their inclination towards budget accommodation, partaking in casual recreation activities, and a high interest placed on meeting both locals and other travellers (Locker-Murphy and Pearce 1995). Murphy adds to this, declaring that backpackers are "young and budget-minded tourists" (2001:50-51). To Ateljevic and Doorne, the label "backpacker" has "become synonymous with a travel style that emphasizes freedom and mobility" (2004:60). Also, backpackers hardly follow norms associated with touristic "types," they often travel for longer and further than most "ordinary" tourists (Riley 1988; Buchanan and Rossetto 1997; Hillman 2001). Uriely, Yonay, and Simchai (2002) found that backpackers are comprised of a mixed group with regard to various reasons and values attached to personal travel experiences, yet, they also appear to enjoy - as a group - a common value in commitment to a non-institutionalized travel, which is ultimately important to their self-identification as "backpackers." This non-institutionalized travel can reference the ability to travel without spending significant amounts of money, in contrast to conventional tourists. Power notes that "[n]orms within the backpacker subculture are based around road status. The less you pay for a journey or a room, et cetera, the more road status you get" (2010:34). As such, it is normal for backpackers to converse over and compare prices paid for different services/activities along their journey (Sørensen 2003; Power 2010). Such behaviors and preferences may coincide with shunning the traditional "tourist" label; a rebellion from that which is conventional in common place to explore the unknown and new. The activity of backpacking itself differs from the common notion of tourism or "the tourist" since the backpacker is anticipated to purposely seek risks rather than avoiding them (Giddens 1991:124). Adkins and Grant suggest that it is important, however, to note the difference between acceptable and avoided risks; “[a]cceptable risks are those that are self-imposed and 'controlled' by the individual as distinct from avoided risks that are imposed by others" (2007:4). They further propose that "this logic of risk is consistent with the motivation of backpacking in terms of self-creation, constituting a way of testing and displaying the capacity to cope with risk appropriately" (Adkins and Grant 2007:4).

Looking at backpackers specifically in the Australian context, studies incorporate other traits aligned with the label. For instance, some studies in the Australian context have noted an increase of backpackers that fall into a higher age category of 26 to 44 year olds (Adkins and Grant 2007). Expanding further, Allon, Bushell, and Anderson (2008) write that:

[i]nternational backpackers are well known for their diverse and independent forms of travel, and their tendency to cross many boundaries in their desire to be on or off the beaten track. However, the mobilities of contemporary backpackers blur as many conceptual and metaphorical boundaries as they do physical ones. Backpackers obviously travel for leisure and pleasure. But, they also increasingly travel and work and study. [p. 7]

These qualities portray backpackers in Australia as older, and pursue activities of work and study as well. Yet, this capacity to work or study in another country diverges from usual notions of backpackers as a type of tourists. Work or study not only overlaps into studies of international students and perhaps workers, but these activities often require a visa allowing such, although merely "backpacking" may or may not require a tourist visa. Examining further how backpackers are able to study or work in Australia, Allon and colleagues (2008) write,

[f]or example, many backpackers apply for Working Holiday Maker visas that allow them to combine periods of work with their travels. The phenomenon of 'student backpackers' also adds to the changing nature of both 'backpacking' and the slippery nature of the traditional difference between work and leisure. The concept of a 'working holiday' disputes the large body of literature that positions tourism in opposition to work. [p. 7]

In this situation, although a backpacker obtains a working holiday visa or travels with study purposes as well, the mark of "backpacker" remains. This aligns those backpackers who work, study, and travel with those backpackers who just simply travel; one name, different activities. Thus, the "slippery nature" mentioned. To Australian tourism 
entities, conversely, the limits are well-defined. Backpackers have been branded by Tourism Research Australia as those who spend at least one night during their trip in a hostel or backpacker accommodation (Buchannan and Rossetto 1997; ATEC 2012). This lone qualifier allows for a very wide construal of the label, and it is assumed the intent of such is simply an attempt to gauge the numbers of "backpackers" who visit the country as to assess aspects of their contribution to the national economy. Yet, there is an inherently wrong use of this idiom as a homogenous concept. To exaggerate, facetiously, if one is 110 year-old grandmother from Timbuktu - or any origin outside Australia for that matter - were to stay in a hostel for one night during a trip to Australia, for whatever purpose of travel, she would effectively have earned the right to be called a "backpacker" in Australia. Pragmatically though, a "backpacker" of such extreme age is a far-fetched notion that many would find difficult to swallow. While, of course, this is a facetious example, it reflects the broad view of whom the phrase "backpacker" in Australia can statistically represent.

If a "backpacker" can be a young budget traveler dedicated to non-institutionalized forms of tourist activity, or any person who lodges in a hostel for one night, or can also be a traveler with a work visa who pursues more than just a holiday in the Australian context - who or what are the limits of the label “backpacker"? Budget, age, risk-taking, and activity inclinations considered, it is still admitted that who exactly is a backpacker is not so clear; there are multiple attributes and aspects to consider. Cohen (2003) states, [f]uture research should desist from referring to backpacking as if it were a homogenous phenomenon, and should pay attention to its diverse manifestations, in terms of difference in age, gender, origins, and particular subcultures. The complex relationship between the domestic, class, ethnic, national, and cultural backgrounds of the backpackers and their trip should be given much more systematic attention than it has received up to now. [p. 106]

This is reiterated within the Australian context as well: "[t]he flexible itinerary, extended stay, and combination of diverse activities (holiday, work, study) have all become characteristics of what defines (or makes definition difficult) of a backpacker today" (Allon, Bushell, and Anderson 2008:7).

With various portrayals or motives, however, it remains hard to determine where the "backpacker" label in general belongs, including the Australian context of such, which this paper is preoccupied with. Consequently, if academia suggests the backgrounds of backpackers and situations should be given more incite into the establishing of who or what a backpacker is, then it is also of interest to further explore defining those who pursue activities understood as in opposition to travel and leisure, namely, the activity of work while traveling.

\section{Working Holiday Makers}

In regards to working holiday makers, like "backpackers," academic descriptions are not so concrete either. A starting point for studying the connection between the two fields of "work" and "holiday" that working holiday makers pursue is with Pape's take on the term "touristy," which incorporates "a form of journeying that depends upon occupation, but only in a secondary sense in that it serves the more primary goal, the travel itself" (1964:337). Some ac-

ademics have even categorized different versions of those who work and travel (see: Cohen 1973; Uriely 2001). Take for instance Uriely's "traveling workers" and "working tourist."

Figure 1. Working Tourists versus Traveling Workers.

\begin{tabular}{|c|c|c|c|c|}
\hline \multicolumn{5}{|c|}{ TYPES OF TRAVELERS } \\
\hline \multirow[b]{2}{*}{$\begin{array}{l}\text { Dimensions of } \\
\text { comparison }\end{array}$} & \multicolumn{2}{|c|}{ WORKING TOURISTS } & \multicolumn{2}{|c|}{ TRAVELING WORKERS } \\
\hline & $\begin{array}{l}\text { Working-holiday } \\
\text { tourists }\end{array}$ & $\begin{array}{l}\text { Non-institutionalized } \\
\text { working tourists }\end{array}$ & Migrant tourism workers & $\begin{array}{c}\text { Traveling professional } \\
\text { workers }\end{array}$ \\
\hline $\begin{array}{l}\text { Work and } \\
\text { touristic } \\
\text { motivations }\end{array}$ & $\begin{array}{l}\text { Work is grasped as } \\
\text { a recreational activity } \\
\text { that is part of the } \\
\text { tourist experience. }\end{array}$ & $\begin{array}{l}\text { Work in order to } \\
\text { finance a prolonged } \\
\text { travel. }\end{array}$ & $\begin{array}{l}\text { Travel in order to 'make } \\
\text { a living' and 'have fun' } \\
\text { at the same time. }\end{array}$ & $\begin{array}{l}\text { Travel in order to exercise } \\
\text { work. Engage in tourist } \\
\text { related activities as a by- } \\
\text {-product of the excursion. }\end{array}$ \\
\hline $\begin{array}{c}\text { Work } \\
\text { characteristics }\end{array}$ & $\begin{array}{l}\text { Unskilled but usually } \\
\text { recreational manual } \\
\text { labor. Extraordinary } \\
\text { work. Unpaid work. }\end{array}$ & $\begin{array}{l}\text { Unskilled and usually } \\
\text { unpleasant manual } \\
\text { labor. Occasional } \\
\text { work. Low-paid and } \\
\text { non-prestigious work. }\end{array}$ & $\begin{array}{l}\text { Skilled or semi-skilled } \\
\text { work in tourism } \\
\text { economy. Repetitive } \\
\text { seasonal employment. } \\
\text { Unsecured and low-paid } \\
\text { employment. }\end{array}$ & $\begin{array}{c}\text { Professional official role } \\
\text { or business related work. } \\
\text { Repetitive, career related } \\
\text { work. Prestigious and } \\
\text { well-paid work. }\end{array}$ \\
\hline $\begin{array}{l}\text { Demographic } \\
\text { profile }\end{array}$ & $\begin{array}{l}\text { Middle-class young } \\
\text { adults }\end{array}$ & $\begin{array}{l}\text { Middle-class young } \\
\text { adults }\end{array}$ & $\begin{array}{l}\text { Lower middle-class } \\
\text { or working class } \\
\text { single and unattached } \\
\text { adults. Periodically } \\
\text { unemployed in their } \\
\text { home societies. }\end{array}$ & $\begin{array}{l}\text { Middle or upper-middle } \\
\text { class adults }\end{array}$ \\
\hline
\end{tabular}

Source: Uriely (2001:5.

A "working tourist" was defined by Uriely and Reichel as "tourists who engage in situations that combine work with tourism" (2000:268). This is a broad categorization as it attempts to embrace all types of travelers who embark upon situations where work and travel are combined. Uriely (2001) put forth the four categories above to differentiate in motivations and characteristics of travelers who pursue work, however, a curious void in categorizations is no differentiation between those with 
a legal right to work; essentially, a working tourist or traveling worker who travels, internationally at least, would be enabled to pursue a wider range of work prospects during travels as governments have provided a legal ability to do so. Our world is one of man-made borders and boundaries not only marked by difference in culture and language but also authority and legal privilege. This missing aspect is plausible, however, in that his categorizations perhaps seek to define terminology abstractly to encompass broader situations of tourist activity that involve work. Nevertheless, Uriely (2001) admits his categorizations only suggest some details of the commonalities in behaviors in which work and tourism intersect.

In the "working tourist" category is where the "working holiday tourist" falls. Their travels are considered a "working holiday," just as a working holiday makers would be. In academia, a "working holiday" has been examined in various research and theory, but most often concerning the working tourists mentioned above. Cohen introduced the plural of the phrase, "working holidays," as a special form of tourism "in which youth from one country travel into another to work for short periods, mostly during summer school vacations" (1973:91). Uriely states that "the term 'working holiday' is attached to various forms of tourism, in which working activity is offered as part of the tourist experience" (2001:4), and, correspondingly, whose practitioners motivations are parallel in explanation. From another view, Wilson, Fisher, and Moore believe that a "working holiday" typically "involves extended stays in other countries by 'holidaymakers' with consequential immersion, to varying degrees, in the economic, social, and cultural dimensions of the host locales" (2009:4). This explanation can be confusing by not mentioning an activity of "work" in its proposal, yet this is probably due to their approach towards their particular conceptual and contextual evaluation. ${ }^{6}$ Empirically, a common academic agreement in definition for a "working holiday" or who a working holiday maker is does not appear to clearly exist, despite the fact a universal foundation of travel activity is apparent.

Abandoning academia and searching for a colloquial definition of a "working holiday" or working holiday maker in the Oxford Dictionary of English, you would find no definition exists. However, in the New Oxford Companion to Law, one does; the definition given for "working holiday" is "[w]orking holiday maker ('WHM') schemes are like super-international exchange programs for young people from selected countries" (2008:1259). Albeit this explanation is of an exchange/visa program more so than an outright definition of activity and motivation for such, it does suggest that a "working holiday" bears correlation with those activities associated with legal work and travel under possession of a visa program of the same name. In fact, as these working holiday visas are offered by numerous nations - Argentina, Canada, Finland, New Zealand, Japan, Ireland, Norway, Germany, plus multiple others, all offer "working holiday" programs and visas - in practice, they are very

${ }^{6}$ Wilson, Fisher, and Moore analyze a "working holiday" in the context of cultural understanding of the traditional Overseas Experience (OE) form of travel undertaken by New Zealand likely what enables pursuit of such activity for "working holiday makers" or "working holiday tourists" contemporarily. Consequently, it is rational to believe that many present understandings of the phrase in various cultural contexts reference such; one can pursue or goes on a "working holiday" to far off countries since a working holiday visa enables them to do so, permitting a legal opportunity to work whilst traveling abroad. As explanations of a "working holiday" vary, further understanding of this concept may appropriately lie in examining the activities involved with travel and work on a working holiday visa to account for actual contemporary practice associated with discourse, identifying working holiday makers as a distinct type of working tourists.

\section{Research and Methodology}

Over the course of just 5 months in Australia in 2011, I embarked on an autoethnographical study of working holiday makers. Utilizing participant observation, I acquired a visa under the WHMP and set out to travel and work in Australia, documenting my experiences along the way, as well as those of other working holiday makers encountered through qualitative interviews. Spending the majority of my time in the cities of Adelaide, Melbourne, Alice Springs, Darwin, and a remote watermelon farm in the outback, I conducted in-depth structured face-to-face interviews with various working holiday makers from around the world. The exact number of interviewees was 22; 7 males and 15 females. Hailing from Germany, Scotland, Canada, U.S.A., Sweden, England, Taiwan, Italy, Norway, Belgium, Denmark, Japan, Estonia, and
France, all except one had WHV 417 visas; the exception having a WHV 462, like myself.

The questionnaire developed prior to research incorporated 85 questions inquiring into various perceptions, activities, and knowledge of WHMs regarding their working holiday experience in Australia; the case of this article analyzing a portion of queries about WHMs self-perceptions and observations of "backpackers" in the context of their "working holiday" in Australia.7 The questionnaire included a mix of yes/no and open-ended questions; open-ended questions were used purposely as, "[a]n open question is one where the range of possible answers is not suggested in the question and which respondents are expected to answer in their own words" (Brace 2004:55). Questions varied, if slightly, only on a handful of occasions due to issues of comprehension on the part of the non-native English speaking respondents and thus, paraphrasing was necessary. As "a tape-recorder is a superior and exact device" (Alasuutari 1995:43), interviews were digitally recorded and conducted in a casual manner with WHMs encountered in the locations mentioned before, ${ }^{8}$ most often at backpacker hostels, who were approached and engaged through a mix of chance and opportunity. Interviews were transcribed with assistance of a paid transcriber, which - according to

${ }^{7}$ For example, questions included: What do backpackers do in Australia? What is a backpacker? Do you consider yourself packer? Why? What do you consider yourself if not a backpacker?
${ }^{8}$.

${ }^{8}$ The locations of interviews, minus a farm where one interview occurred, all took place in areas/towns/cities identified in 2009's
Evaluation of Australia's Working Holiday Maker Program as major locales frequented by WHMs (see: http://www.immi.gov.au/ media/publications/research/_pdf/whm-report.pdf). 
Seidman - is "the ideal solution for the researcher" (1998:98), and texts were verified with corresponding audio files to ensure accuracy of transcription. My own experiences as a WHM were recorded in a digital field journal that served to document the participant observation portion of my research as a WHM myself.

Interview data was analyzed using a "modified" thematic analysis; a thematic analysis being a method "often used in a common-sense way to refer to patterns in the data that reveal something of interest regarding the research topic at hand" (King and Horrocks 2010:149). Patterns are categorized and coded into themes, and deciding on what constitutes a "theme" involves "the researcher in making choices about what to include, what to discard, and how to interpret participants' words" (King and Horrocks 2010:149). Themes that are included by the researcher are often directly involved with the research questions or topic at hand and, ultimately, I followed King and Horrocks' definition of a theme in analysis: "[t]hemes are recurrent and distinctive features of participants' accounts, characterizing particular perceptions and/or experiences, which the researcher sees as relevant to the research question" (2010:150).

The modified thematic analysis was based on standard approaches put forth by other academics (see: Langdridge 2004; Braun and Clarke 2006; King and Horrocks 2010), yet diverged in that it was performed to the style that fits my approach of analysis; rather than copy the steps of how one "should" do an analysis as proposed by other academics with their own distinct research topics, I chose an approach that made sense in a candid procedure relevant to my question types and overall research methodology that also incorporated autoethnographic participant observation. The steps/stages for scrutinizing the interview data for analysis are presented in Figure 2.

As Aldridge writes, "sociological methods texts... deal rather with what sociologists contend happens when research is carried out, and not with how sociologists go about the process of translating the research' - a multifaceted experience in time - into a piece of writing" (1993:54). Ultimately, the themes identified from my modified thematic analysis with respect to my "multifaceted experience in time" will be evident later on in the discussion points of this article, with the identified themes of discovery relayed to the reader.

Regarding participant observation data recorded in my field journal, the analysis process involved reading through the journal several times, end-to-end, pinpointing my own experiences and observations with respects to "backpackers" in my "working holiday" context in Australia. Rather than thematically classifying these observations in text, field notes served as empirical examples to accentuate revelations discerned from interview text.

The pragmatic modified thematic analysis supplemented by participant observation insights proved rational in that respondent data was not the sole source of actualities within my research and needed to emphasize, yet not necessarily dwarf, the first-person ethnographic experience as a WHM, and vice-versa. As Aldridge marks, "in ethnographic writing, there is no standard move to ex-
Figure 2. Steps of thematic analysis.

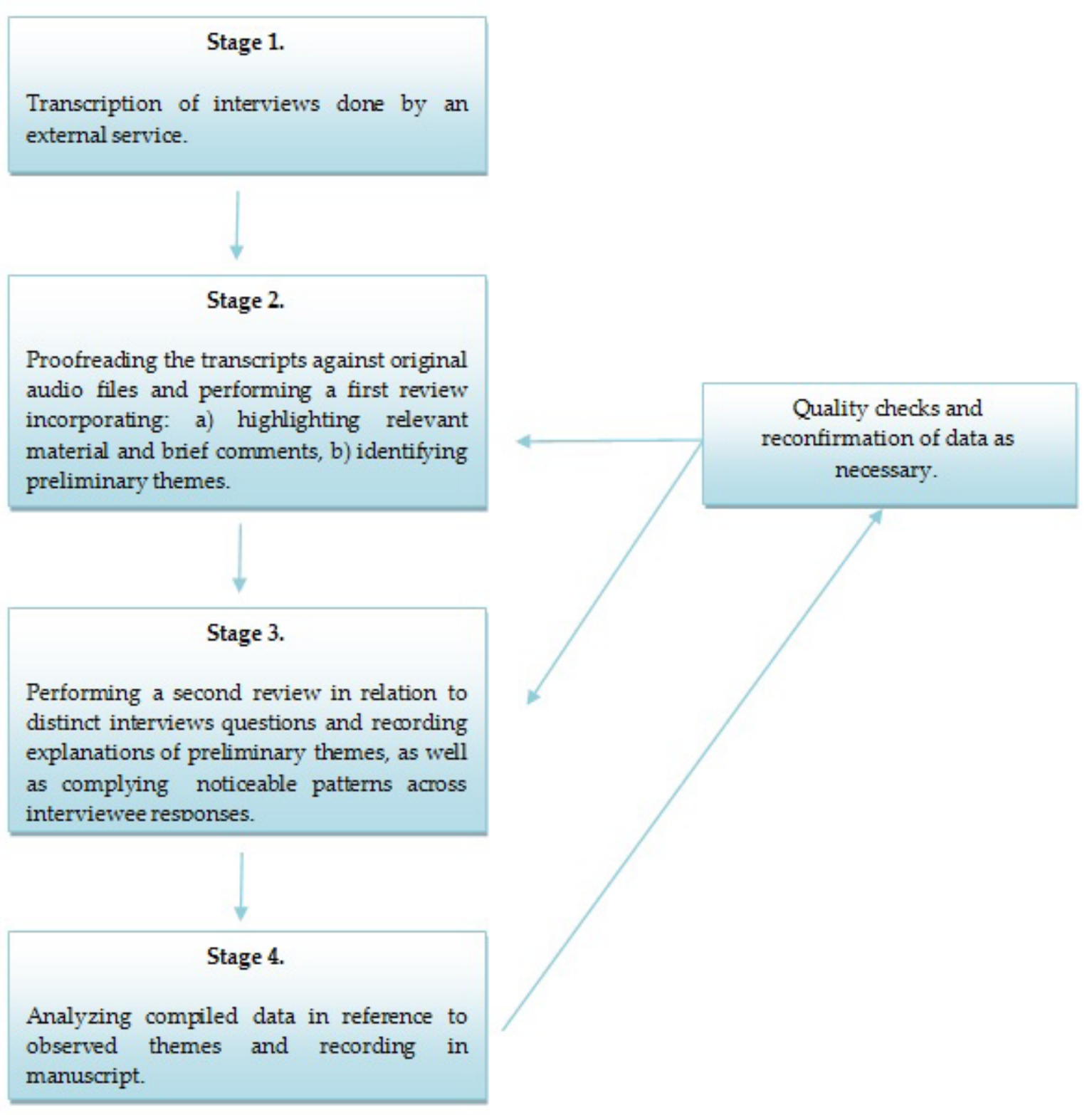

Source: self-elaboration

cise presentation of the researcher's presence within the research," yet, "there are still standard structural and rhetorical means of producing and presenting such accounts which 'scientize' them and the researcher who produces them" (1993:56). As the researcher and autoethnographer, my role is as interpreter of the data collected and I approached it with an analytical process which I saw fit as efficient taking into account my distinct methodology, yet still bore structure similar to those which I believe "scientize" such.

In reflecting on the open-ended, sometimes obscure, academic definitions surrounding "backpackers," 
what autoethnographic participant observation and qualitative interviews provided is an alternative approach to the understanding of how not all international travelers in Australia should necessarily be grouped as one homogenous horde. The overall inquiry of research was with working holiday makers' situations as workers, with one focus on gaining understanding, through ethnographic participation, of how a labeling as "backpacker" could potentially effect treatment as workers with legal entitlements. As a WHM, I participated fully like others around me and similar to those previously studied, undertaking paid employment. Thus, my working holiday became both a research setting and an object of study, and my role as WHM and researcher demanded a thorough ethnographic immersion in the field on a continual day-to-day basis. While qualitative interviews gave light to the experiences and perceptions of other WHMs, the methodological advantages of autoethnography were twofold; I was able to experience the practicalities and realities of traversing Australia as a WHM, appreciating their "lived realities" (Mason 1996; Brewer 2000), and I was able to reflect ethnographically on my position as a foreign working tourist in an understanding and account of how backpackers and WHMs are often categorically grouped together.

Autoethnography can hence be explained as an ethnography in which the researcher is a full member within the research setting, and visible in the text, focused on developing sociological elaborations of a broader phenomena (Anderson 2006). Due to my participant observation role of being a WHM myself, autoethnography as a medium in which to present my findings proved a logical method; per- sonal experiences in the field were pertinent to the study, and thus, writing is more reflective when transferring not just interviewees' notes and transcriptions to paper but also my own perceptions. In this construction of the ethnographic description, this data provided an account and chronology of the ethnographic experience. The combination of qualitative interviews serves to complement first-hand experiences and empiricism, and draw further scrutiny in identifying characteristics and behaviors of working holiday makers as similar to, or diverse from, pre-existing "backpacker" physiognomies. As Anderson writes, "[a]utoethnographers should illustrate analytic insights through recounting their own experiences and thoughts, as well as those of others" (2006:384). The interview transcriptions were reviewed using a modified thematic analysis identified patterns and themes in response to the specific topics of inquiry, and as Leninger points out, the "coherence of ideas rests with the analyst who has rigorously studied how different ideas or components fit together in a meaningful way when linked together" (1985:60).

In reality, my personal experience on a working holiday, and those of 22 interviewees, is of course difficult to directly generalize to those of all 185,000 working holiday makers also in Australia in June of 2011,9 or further, those who have embarked on a "working holiday" to Australia over the past several years. Australia is with no doubt a huge country and continent, yet generalizabili-

${ }_{9}^{9}$ According to the Australian Tourism Export Council, there were more than 185,000 international tourists holding a WHV
417 in June 2011, this includes both $1^{\text {st }}$ and $2^{\text {nd }}$ year visa holders, yet does not include all of those, also in Australia, on WHV 462. ty is still important in qualitative research when incorporating methodological transparency and parameters of research are presented with significance. In autoethnography, the emphasis of generalizability transfers from respondents to readers, constantly tested as readers conclude if the authors accounts resonate with them about their own lives or about the experiences of others they hear about; are the autoethnographers' specific accounts able to explain general, unfamiliar processes (Ellis and Bochner 2000). What I ultimately hope to accomplish is to offer a glimpse into the world of WHMs to the outsider reader, articulating my own experiences and the perceptions of other WHMs throughout their experiences in various locations in Australia, supplemented by theory and empirical observation. Readers and academics will have to make their own judgment of the validity of my research, and I have pondered how to accurately convey that which is an honest and open account of what my research has produced, which I will now discuss results of.

\section{Backpackers or Working Holiday Makers?}

The given characteristics commonly associated with "backpackers" in academic studies were facets utilized in both cognizance and divergence from the label as recognized by WHMs encountered during my research, as well as in my own participant observation. The notion of work mentioned in the Australian backpacker context was also a point of discussion. While some WHMs identified themselves outright as indeed being "backpackers" after multiple inquiries with varying angles of perspective, a portion provided curious responses; some identifying as backpackers yet different, or rejecting the label altogether:

Me: What is a backpacker?

Carol (Germany): Backpacker is people with a working holiday visa.

Me: Okay, and are you a backpacker?

Carol (Germany): Yes.

No [I don't see myself as a backpacker]. Um, because I'm working... I can afford accommodation and I can afford food. Like I can go "here" - because I'm working. [Jackie, England]

I, myself, was put to a test of self-assessment as in one of my situations of employment when referred to simply as a "backpacker" on a work site, over and over again. Ultimately, determinants in which WHMs seemingly drifted away from semblance with young budget tourists were with respect to perceptions about money expenditure and the activity of working.

\section{I'm Not a "Backpacker" - I Work}

During my research, I was employed as a bartender, automobile detailer, fruit picker, and worked at a hostel in exchange for accommodation. On one occasion, during my employment as a detailer, the girlfriend of one of my supervisors - visiting our worksite as she did often - told me I was "the best backpacker they'd ever had [working for the company]," hinting that although my work performance may be better than those charged with similar tasks in the past, I was also apparently still a young budget tourist. The best "backpacker" 
they had ever had? After a short pause, I replied, "I'm not a backpacker," I denied the label of being simply a young budget tourist. Beyond the research aspect of my "working holiday," I had been working and living in the city where my employment was located for over a month; I was not traveling or passing through town, nor was my act of showing up for work each day a tourist activity. Further, in my own position as a WHM, in addition to a researcher, the fact that I was employed and was trying to earn money by staying for a prolonged period in one place rather than avoiding ways of spending money while "on the road," as Power (2010) states, disconnected me from any such label. While this experience may be scrutinized as a subjective personal one, several other WHMs interviewed inferred a similar outlook as myself, eluding to a work and living difference:

I think I'm not quite a backpacker. Maybe sometimes, but yeah, I think I'm not a backpacker. I'm just a visitor who wants to work and I think I'm not a tourist, but - I think, not, not me, I think I'm not special one, but because I want to stay in one place.... and I think I'm rather resident than backpacker because I move when I get another job or I need to find something else. [Matt, Estonia]

This residing in one place aspect, even if temporary, is also mentioned by Jarvis and Peel who found that WHMs, during their stay in Mildura as fruit pickers, tend to live "like locals," spending their money on accommodation, food, and leisure activities within the city (2010:7). Somehow, this seems only logical; when working, WHMs are often staying in one location, thus activities become more routine with work responsibilities and everyday living. Yet, this is not to say though that when they do travel, WHMs do liken themselves to backpackers:

Me: Okay. Uh, do you guys, do you consider yourselves backpackers?

David (Sweden): Yeah, for now I do.

Nancy (Sweden): At the moment yeah.

David (Sweden): At the moment yeah.

Me: But, are there other moments when you see yourself as different from a backpacker?

David (Sweden): Yeah.

Nancy (Sweden): When we are working, when I'm at work, then I see myself like, yeah, I'm here and I'm working and I meet lots of people here at work. And then...

David (Sweden): We're seeming like backpackers when we are in Sydney [where they first arrived to Australia and went sightseeing].

Nancy (Sweden): Yeah.

This association with backpackers by WHMs in identifying with the label yet diverging at times seems due with respect to the activity of pursuit. When WHMs are working, they are not on holiday, and thus are divergent from a backpacker or tourist. When one is not working or traveling, then they are more so on holiday and more likened to a backpacker or tourist. But, while both backpackers and WHMs may share an easily discernable activity of travel, grouping the two into the same homogenous category can be tricky. Not all backpackers, in the Australia context, necessarily have a legal right to work, nor is their nationality limited to being from a certain country, or their age restricted to a minimum or maximum, unlike WHMs. Further, in seeking, and having a legal right to work, WHMs may have a different priority in expenditure than backpackers as they endeavor to earn money to supplement a trip as opposed to not spending money in hopes of making a holiday last longer. The result of working, naturally, is having money to spend.

\section{Money Matters}

With a preference for budget travel and avoidance at spending money (Loker-Murphy and Pearce 1995; Murphy 2001; Power 2010), backpackers sometimes seek to get "something for nothing." While working in a hostel, I encountered on numerous occasions young travelers trying to use the facilities for an extra night without paying - by returning to the premises after the manager had left, as they still had the access code to enter the front gate from their previous night's stay. I was able to observe this as many either did not seem to know that I was informally working at the hostel or they thought I would not care since I was perceived as a "backpacker" just like them. While they did not have a bed or dormitory to sleep in, they most often would return to the property to use cooking and bathroom facilities without charge. But, to the manager, this was everyday behavior for "backpackers." In discussions with him about these incidents, his opinions match that of Sørensen's (2003) and Power's (2010), observing that it is normal for backpackers to discuss and compare prices paid for different services/activities along their route. According to him, when backpackers can sneak in and use facilities for free, they share this knowledge of chicanery, and the name of the hostel where they successfully got away with it, with other backpackers along their journeys; the more backpackers that know about an alleged opportunity to get something for free, the more who will attempt to abuse it. Such issue of money expenditure came up in research interviews, when explaining why she was a backpacker, one Dutch WHM cited her lack of money:

Me: Uh, do you consider yourself a backpacker? Wendy (Netherlands): I think yes. I'm traveling from city to city and if you describe as....well, backpackers, they live on pasta and rice because it's cheap. They only eat the cheapest.

Me: So you consider yourself a backpacker because of your diet?

Wendy (Netherlands): No. I think that's why I'm sleeping in hostels and don't have money anymore...

A situation of destituteness linked with backpackers was reiterated by another WHM:

Me: Okay. So, what is a backpacker?

Dustin (Germany): Um, somebody traveling around, living sometimes in the car and hostels. Somebody who has no home here in Australia, and has to take care of his money because maybe it is not really a lot.

Me: Okay. Do you consider yourself a backpacker? Dustin (Germany): Yes.

Both reiterate academics who state the backpackers' preference for budget travel (Loker-Murphy and Pearce 1995; Sørensen 2003). Yet in contrast, another WHM noted she was not preoccupied with living a lifestyle of budget travel: 
Me: Okay, do you consider yourself a backpacker? Erica (Scotland): Sometimes.

Me: Sometimes you don't?

Erica (Scotland): I don't. I feel I need my comforts too much.

Me: So then, what do you consider yourself then if not a backpacker at those times?

Erica (Scotland): I don't know... Someone sort of posing as one a lot of times.

Posing as a "backpacker" reflects Power's (2010) reference to "road status" as important to backpackers; perhaps backpackers "should" be budget minded, just as another interviewee inferred:

Me: So, can you tell me what is a backpacker?

Helen (Germany): Well, a backpacker - has a backpack...and, um, they actually are traveling around a little bit. Often, it's a low cost and, yeah, sometimes I think it is nothing really planned. You meet other people who have got other ideas and so you join them, you don't join them. You are kind of free of doing anything that you want.

Me: Okay... Uh, are you a backpacker?

Helen (Germany): Well, yes. Well, I am trying to be one.

Such revelation again echoes a connection with low-cost travel and backpackers, yet no mention of work is given, despite their pursuit of work at some point in their journey.

\section{Numbers}

In discussing the "slippery nature" of identifying the characteristics of backpackers (Allon, Bushell, and Anderson 2008), it is pertinent to mention that when studies of backpackers in Australia first emerged in the early 90s (Pearce 1990; Loker 1993; Loker-Murphy and Pierce 1995), only the UK, Canada, Ireland, the Netherlands, and Japan were apart of the WHMP at that time, with roughly 44,000 WHV arrivals in 1990. WHV arrivals had risen to roughly 60,000 when the Bureau of Tourism Research published its "With My Swag Upon My Shoulder: A Comprehensive Study of International Backpackers to Australia" in 1997, which mentions backpackers who work, yet not WHMs specifically. The WHMP expanded significantly in 2000, with the inclusion of 17 new countries between 2000-2007, resulting in roughly 134,000 WHV arrivals by 2007, nearly triple that of arrivals in 1990. Around this time, it seems, studies of backpackers began featuring WHMs and backpacker activities as including work and studying, going further than previous focus on characteristics of budget travel preferences (Adkins and Grant 2007; Allon, Bushell, and Anderson 2008). Empirically speaking, although distinct studies about WHMs which have occurred since at least 1991 (see: Dignam 1990; Withers 1991; Bell and Carr 1994; Brooks, Murphy, and Williams 1994; Murphy 1995; Parliamentary Joint Standing Committee on Migration 1997; Harding and Webster 2002; Tan et al. 2009) often related to government interest, it appears that academic portrayals of backpackers as being able to work and study emerged as an increase in WHMP participants did; between 2004-2005 and 2007-2008, WHM arrival numbers increased by 15.6\% (see Figures 3 and 4).

As the WHMP has allowed more young international persons the ability to travel to and around Australia, supplemented by the capacity to work, subsequently, those doing so may have been simply incorporat-

\section{Figure 3. WHM visas issued 1983-2009.}

\section{WHM Visas issued 1983/84 - 2008/09}

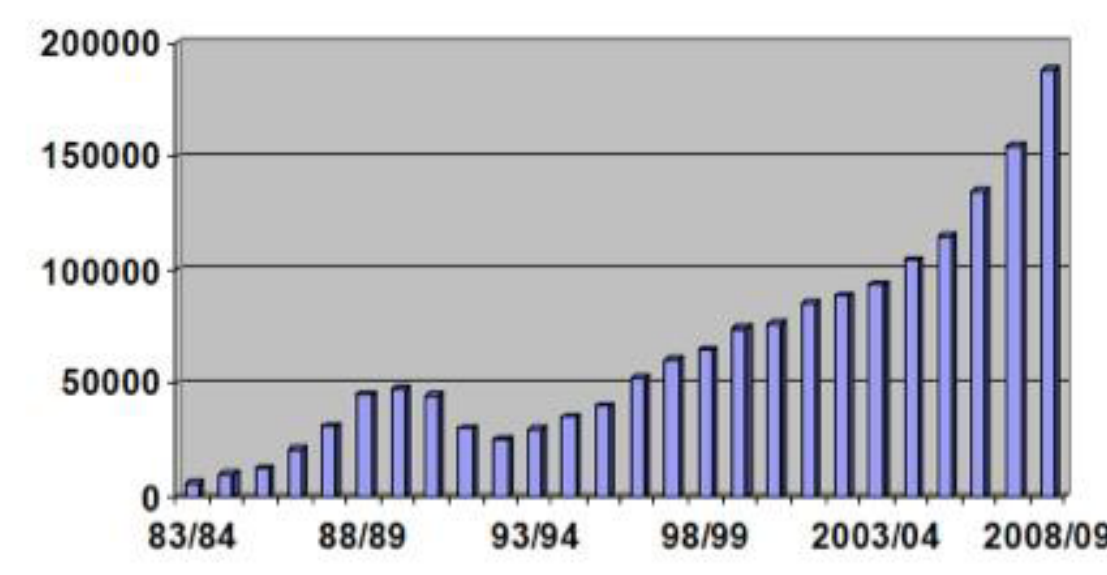

Source: Jarvis and Peel (2010:10).

Figure 4. Backpacker arrivals 1999-2008.

\section{Backpacker Arrivals 1999/2000-2007/08}

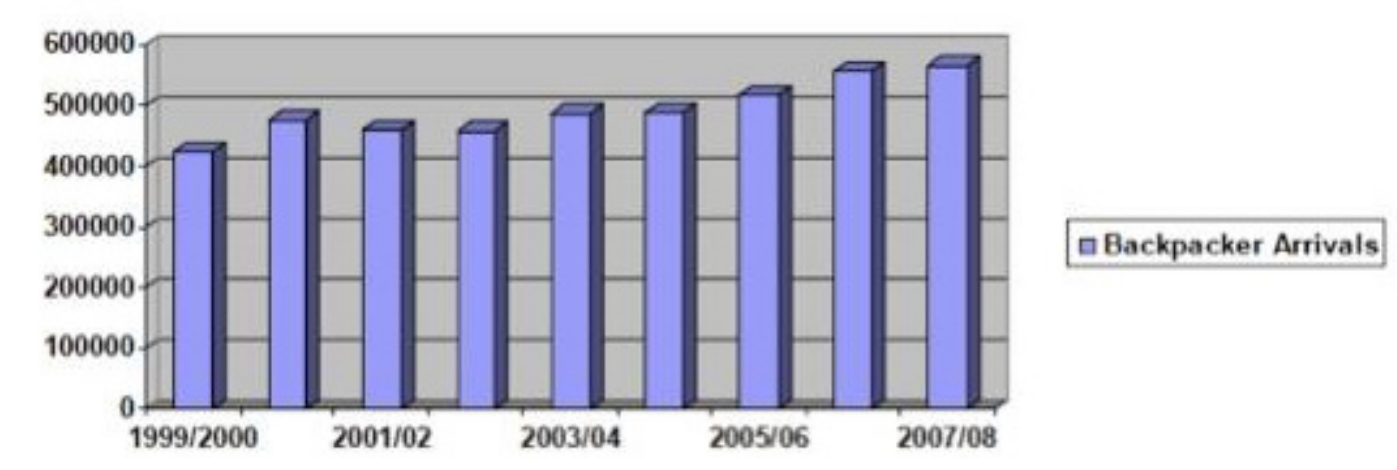

Source: Jarvis and Peel (2010:11).

ed into the category "backpackers" - those travelers commonly prevalent in Australia prior. So, while distinctly different in visa category and entitlements of work activity, some academic definitions of "back- packers" simply evolved to include WHMs due to informal classifications. Beyond theory though, those who travel with a WHV must deal with non-academics in reality, such as employers, whose questionable 
intentions towards backpackers as employees can affect the work environment for WHMs.

\section{Implications}

While a "working holiday" in Australia empirically is marketed primarily as a tourist adventure for prospective backpacker with an option to work, there is a cognizant effort in previous studies to examine the potential effects, positive or negative, of this foreign population that can be viewed as a labor force or supply among the national populous; they are recognized as workers beyond tourists or "backpackers." Studies concluded that the tourist spending of WHMs is so substantial that they actually create more jobs in Australia than they take (Harding and Webster 2002; Tan et al. 2009), hence justifying continuation and expansion of the WHMP. Despite these revelations, one area these studies do not cover is the work conditions of WHMs, even acknowledged by Tan and colleagues (2009).

Such a void appears consistent among academic studies of WHMs specifically, however, insights into such exist in studies that incorporate them, such as those of backpackers mentioned earlier. For example, Allon and colleagues found that WHMs, among backpackers in Sydney, faced low wages and disrespectful behavior by employers (2008:47), even going so far as to being called by many businesses in Sydney as "Australia's Mexicans," insinuating their use as similar to that of low-wage temporary Mexican migrant workers in the U.S.A. (2008:11). Further, in their work as fruit pickers or farm workers, WHMs are reported as susceptible to receiving wage rates and working conditions below national standards or experience racist behavior from growers (Mares 2005:2-3). Situations such as these are often characteristic of precarious work positions; employment settings in which workers are vulnerable to exploitation or sub-standard, often illegal, working conditions.

As WHMs are not just on a traditional holiday, undertaking paid employment in Australia, some of their activities and behaviors diverge from that of tourist backpackers, as discovered in research. Even if tourists in some regards, discriminatory or detrimental treatment in employment for WHMs when merely viewed as backpackers is not only damaging in that it lessens a universal call for fair treatment for workers but can also put WHMs personal safety at risk if undertaking jobs in which their rights, safety, or health is not of paramount concern to unscrupulous employers who view international working tourists entitled to legal standards of work as simply "backpacker" labor. Take for example the death of WHM Jessica Pera in 2009, who dropped dead while on her second day of picking tomatoes after less than 3 months in Australia.

Jessica's death was concluded as a possible result of dehydration caused by heat stress, although findings were officially inconclusive per coroner's report. Nonetheless, Barbera Farms, one of Australia's largest suppliers of tomatoes, capsicums, and zucchinis, where Jessica was working, was fined $\$ 25,000$ in response to the tragedy upon discovery the farm neglected to safeguard workers against heat stress, having failed to supply drinking water or other means of rehydration for workers, nor offering shading on the day she died. Additionally, the farm also failed to check if workers were using sun protection equipment to reduce the risk of heat stress, exhaustion, or hyperpyrexia, which can occur due to extreme working temperatures. Even further, the farm similarly failed to give ample information, training and induction, as well as supervision to ensure workplace health and safety. In the end, a court concluded farm managers failed to recognize or practice safe guidelines in the work environment leaving their backpacker workers at risk of injury or death, and the potential for detriment was evident (Feneley 2010; Marsh 2010; 2011; Bentley 2011). One media report discussing this event even included the "backpacker" association with this workplace tragedy in their title - "Backpackers Want a Tan to Die For" (Andersen 2011). While the death of a "backpacker" is an extreme case in workplace hazard, the most common form of violation is cheating or withholding of wages, with reports of such still maintaining the "backpacker" association - "Fears Backpacker Farm Workers Exploited" (Edwards 2013).

Such close association between backpackers and WHMs in Australia is evident, and although hard not to say WHMs may be spending conscious like backpackers or other young budget tourists, WHMs have a legal right to work. And with this right, there is a reasonable assumption on their

\section{References}

Adkins, Barbara A. and Eryn L. Grant. 2007. “Backpackers as a Community of Strangers: The Interaction Order of an Online Backpacker Notice Board." Qualitative Sociology Review 3(2):188-201.

Alasuutari, Pertti. 1995. Researching Culture: Qualitative Method and Cultural Studies. London: Sage. part that comes with this legal right - to perhaps be treated as a legitimate worker entitled to a safe work environment.

\section{Further Research}

While this article may imply further interest about the working conditions of WHMs in Australia, the main focus is simply to demonstrate a potential divergence between the backpacker and working holiday maker label; one is perhaps more so a young budget-minded tourist or traveler, and the other a working tourist. While backpacker activities may have evolved empirically and within academia to incorporate an aspect of work in the Australia context as discussed, there are perhaps negative real world ramifications that come with the continuation of this young budget tourist label associated with those who seek a legitimate right to work. Ultimately, this article argues that further research needs to be carried out on WHMs as this form of travel, and labor mobility scheme, is expanding globally, and as the results of academic research potentially influence public opinion and policy, further respect to legal activities of work for international travelers, or any workers in general, holds implications with respect to safe work environments.

Aldridge, Judith. 1993. “The Textual Disembodiment of Knowledge in Research Account Writing." Sociology 27(1):53-66.

Allon, Fiona, Robyn Bushell, and Kay Anderson. 2008. Backpackers in Global Sydney. Sydney: Centre for Cultural Research, University of Western Sydney. 
Andersen, John. 2011. "Backpackers Want a Tan to Die For." Townsville Bulletin, November 5.

Anderson, Leon. 2006. "Analytic Autoethnography." Journal of Contemporary Ethnography 35(4):373-395.

Ateljevic, Irena and Stephen Doorne. 2004. “Theoretical Encounters: A Review of Backpacker Literature." Pp. 60-76 in The Global Nomad: Backpacker Travel in Theory and Practice, edited by G. Richards, J. Wilson. Clevedon: Channel View Publications.

Australian Tourism Export Council. 2012. "The Importance of the Working Holiday Visa (Subclass 417)." Retrieved March 22, 2014 (https://www.atec.net.au/files/0595_WHV_PositionPaper_ LowRes_23Feb12.pdf).

Bell, Martin and Rick Carr. 1994. Japanese Temporary Residents in the Cairns Tourism Industry. Canberra: Australian Bureau of Immigration and Population Research.

Bentley, Amelia. 2011. “Farm Guilty of Neglect on Day of Fruit Picker's Death." Brisbane Times, June 9.

Brace, Ian. 2004. Questionnaire Design. London: Kogan Page.

Braun, Virginia and Victoria Clarke. 2006. “Using Thematic Analysis in Psychology." Qualitative Research in Psychology 3(2):77-101.

Brewer, John D. 2000. Ethnography. Buckingham: Open University Press.

Brooks Clive, Jill Murphy, and Lynne S. Williams. 1994. Skilled Temporary Residents: Rationale and Labor Market Effects. Canberra: Australian Government Publication Service.

Buchanan, Ian and Allison Rossetto. 1997. "With My Swag Upon My Shoulder." Occasional Paper No. 24. Canberra: Bureau of Tourism Research

Cane, Peter and Joanne Conaghan, (eds.). 2008. The New Oxford Companion to Law. Oxford, New York: Oxford University Press.

Cohen, Erik. 1973. “Nomads From Affluence: Notes on the Phenomenon of Drifter Tourism." International Journal of Comparative Sociology 14:89-103.
Cohen, Erik. 2003. “Backpacking: Diversity and Change.” Tourism and Cultural Change 1(2):95-110.

Colley, Clare. 2013. “We Rely on Backpackers: Gaeta." Central Western Daily, January 17.

Department of Immigration and Citizenship. 2012. Workin Holiday Maker Visa Program Report. Retrieved March 07, 2013 (http://www.immi.gov.au/media/statistics/pdf/working-holiday-report-jun12.pdf).

Dignam, Mark. 1990. Temporary Overseas Workers Study: A Research Report on the Usage of and Attitudes Toward Working Holiday Makers and Overseas Students in Selected Industries in Australia. Canberra: Bureau of Immigration Research.

Edwards, Alyse. 2013. “Fears Backpacker Farm Workers Exploited." ABC News, March 20.

Ellis, Carolyn and Arthur P. Bochner. 2000. "Autoethnography, Personal Narrative, Reflexivity." Pp. 733-768 in Handbook of Qualitative Research, edited by N. K. Denzin, Y. S. Lincoln. Thousand Oaks: Sage.

Feneley, Rick. 2010. “How Did Our Daughter Die? Parents Demand Some Answers." The Sydney Morning Herald, March 13.

Gallus, Chris, (ed.). 1997. Working Holiday Makers: More Than Tourists. Canberra: Australia Government Publishing Service.

Giddens, Anthony. 1991. Modernity and Self-Identity: Self and Society in the Late Modern Age. Stanford: Stanford University Press.

Harding, Glenys and Elizabeth Webster. 2002. The Working Holiday Maker Scheme and the Australian Labor Market. Melbourne: Melbourne Institute of Applied Economic and Social Research, University of Melbourne.

Hillman, Wendy. 2001. "Searching for Authenticity and Experience: Backpackers Traveling in Australia." Paper presented at TASA 2001 Conference, 13-15 December, University of Sydney.

Jarvis, Jeff and Victoria Peel. 2010. "Long Term Tourists or Shor Term Migrants." The Impact of International Working Holiday Maker
(WHMs) on the Tourism Economy of Mildura in Regional Victoria 20092010. Retrieved May 21, 2014 (http://www.tourism.vic.gov.au/images/stories/Documents/Marketing/whms-mildura-2009v2010-tv2. pdf

Jensen, Erik. 2009. “Blitz on Working Holiday Visa Scam." The Sydney Morning Herald, November 28

Kawashima, Kumiko. 2010. “Japanese Working Holiday Makers in Australia and Their Relationship to the Japanese Labor Market: Before and After." Asian Studies Review 34(3):267-286

King, Nigel and Christine Horrocks. 2010. Interviews in Qualitative Research. London: Sage.

Langdridge, Darren. 2004. Introduction to Research Methods and Data Analysis in Psychology. Harlow: Pearson Education.

Leininger, Madeleine M., (ed.). 1985. "Ethnography and Ethnonursing: Models and Modes of Qualitative Data Analysis." Pp. 33-72 in Qualitative Research Methods in Nursing. Orlando: Grune \& Stratton.

Loker, Laurie. 1993. Backpacker Phenomenon II: More Answers to Further Questions. Townsville: James Cook University of North Queensland.

Loker-Murphy, Laurie and Philip L. Pearce. 1995. “Young Budget Travelers: Backpackers in Australia." Annals of Tourism Research 22(4):819-843.

Mares, Peter. 2005. "Seasonal Migrant Labor: A Boon for Australian Country Towns?" The Changing Nature of Country Towns. Retrieved April 11, 2013 (http://www.sisr.net/flagships/democracy/projects/publications/05mares.pdf)

Marsh, Vanessa. 2010. "Answers Wanted for Mystery Death." NewsMail, March 17.

Marsh, Vanessa. 2011. "Parents' Anguish a Mystery Death." NewsMail, June 18

Mason, Jennifer. 1996. Qualitative Researching. London: Sage.
Murphy, Jill. 1995. The Labor Market Effects of Working Holiday Makers. Canberra: Australian Government Publication Service.

Murphy, Laurie. 2001. “Exploring Social Interactions of Backpackers." Annals of Tourism Research 28:50-67.

Opie, Kaitlyn. 2013. “Hopping Mad: Backpackers Fume Over Broken Promise of Fruit-Picking Work." Sunraysia Daily, February 01

Pape, Ruth H. 1964. “Touristry: A Type of Occupational Mobility." Social Problems 11(4):336-344.

Parliamentary Joint Standing Committee on Migration. 1997. Working Holiday Makers: More than Tourists. Canberra: Australian Government Publication Service.

Pearce, Philip L. 1990. The Backpacker Phenomenon: Preliminary Answers to Basic Questions. Townsville: James Cook University of North Queensland.

Power, Louise. 2010. "Backpackers as a Subculture." Socheolas Limerick Student Journal of Sociology 3(1):25-37.

Riley, Pamela. 1988. “Road Culture of International Long-Term Budget Travelers." Annals of Tourism Research 15(3):313-328.

Seidman, Irving. 1998. Interviewing as Qualitative Research A Guide for Researchers in Education and the Social Sciences. London: Teachers College Press.

Sørensen, Anders. 2003. "Backpacker Ethnography." Annals of Tourism Research 30(4):847-867.

Tan, Yan et al. 2009. Evaluation of Australia's Working Holiday Maker (WHM) Program. Canberra: Department of Immigration and Citizenship.

The Age. 2008. "Record Number of Backpackers Receive Working Holiday Visas." Retrieved December 122013 (http:// www.theage.com.au/travel/travel-news/record-number-of-backpackers-receive-working-holiday-visas-20081113-60k0.html).

Tovey, Josephine. 2012. "Backpackers Paid to Spruik Living Sydney Candidates." The Sydney Morning Herald, September 9. 
Uriely, Natan. 2001. “'Travelling Workers' and 'Working Tourists': Variations Across the Interaction Between Work and Tourism." International Journal of Tourism Research 1(3):1-8.

Uriely, Natan and Arie Reichel. 2000. “Working Tourists and Their Attitudes to Hosts." Annals of Tourism Research 27(2):267-283.

Uriely, Natan, Yuval Yonay, and Dalit Simchai. 2002. "Backpacking Experiences: A Type and Form Analysis." Annals of Tourism Research 29(2):520-538.
Walliker, Annalise. 2007. "Backpackers Head Our Way." The Herald Sun, July 26.

Wilson, Jude, David Fisher, and Kevin Moore. 2009. “The OE Goes 'Home': Cultural Aspects of a Working Holiday Experience." Tourist Studies 9(1):3-21.

Withers, Glenn. 1991. The Working Holiday Maker Program: A Report by a Working Party of the National Population Council. Canberra: Australian Government Publication Service.

Brennan, Christopher. 2014. "Backpackers or Working Holiday Makers? Working Tourists in Australia." Qualitative Sociology Review 10(3):94-114. Retrieved Month, Year (http://www.qualitativesociologyreview.org/ENG/archive_eng.php). 